\title{
HUKUM BERPUASA DALAM KONDISI PANDEMI COVID-19
}

\author{
Gampang Dadiyono \\ Sekolah Tinggi Ilmu Islam dan Bahasa Arab (STIBA) Makassar \\ Email: paesarah.gampang@stiba.ac.id \\ Marzuki Umar \\ Sekolah Tinggi Ilmu Islam dan Bahasa Arab (STIBA) Makassar \\ Email: marzukiumar.lc@gmail.com
}

\begin{abstract}
Keywords:
ABSTRACT

Fasting, Covid-19, Positive, This research was conducted with the aim to explain the law of Worker, and Medical fasting during the Covid-19 pandemic upon those who are Covid19 positive, those who were Covid-19 positive yet asymptomatic, and health workers who treat Covid-19 patients. This research used a qualitative approach using content analysis and library research. The results showed that, first, people who are Covid-19 positive are considered sick so that they have excuse to break the fasting; Second, those who are Covid-19 positive but show no symptoms are considered sick people so that they may not fast; Third, those who are still healthy and have not been infected with Covid-19 and have met the conditions of fasting and have no excuse that prevent them from fasting then it is obligatory upon them to fast; Fourth, medical workers who treat Covid-19 patients are still required to fast. If in conducting their duties they are very thirsty, hungry, or exhausted who are feared to be vulnerable to falling ill and be infected with Covid-19, then they may break their fast.
\end{abstract}

Kata kunci: $\quad$ ABSTRAK

Puasa, Covid-19, Positif, Penelitian ini dilakukan dengan tujuan untuk menjelaskan hukum Tenaga, dan Medis. $\quad$ puasa dalam masa pandemi covid-19 baik bagi orang-orang yang positif terpapar covid-19, mereka yang positif covid-19 namun tidak menunjukkan gejala, dan para tenaga kesehatan yang menangani pasien covid-19. Penelitian ini menggunakan metode pendekatan kualitatif dengan menggunakan teknik content analysis (analisis isi) dan riset kepustakaan (library research). Hasil penelitian menunjukkan bahwa: pertama, orang-orang yang positif terpapar penyakit virus covid-19 adalah mereka yang tergolong sakit yang bisa mendapatkan uzur untuk tidak berpuasa; kedua, mereka yang positif covid-19 namun tidak menunjukkan gejala, maka dihukumi sebagai orang sakit sehingga boleh untuk tidak berpuasa; ketiga, mereka yang masih sehat dan belum terinfeksi virus covid-19 dan terpenuhi atasnya syarat-syarat puasa dan tidak memiliki uzur yang menghalanginya untuk berpuasa maka wajib baginya untuk berpuasa; keempat, tenaga medis yang menangani pasien covid-19 tetap wajib berpuasa. Apabila dalam menjalankan 


\section{PENDAHULUAN}

Puasa Ramadan merupakan ibadah yang hukumnya wajib berdasarkan firman Allah Ta'ala:



Terjemahnya:

"Wahai orang-orang yang beriman, diwajibkan atas kamu berpuasa sebagaimana diwajibkan atas orang-orang sebelum kamu agar kalian bertakwa." (Q.S. al-Baqarah/2: 183).

Selain dalil tersebut, puasa Ramadan merupakan salah satu dari rukun Islam yang lima. Nabi Shallallahu 'Alaihi Wasallam bersabda:

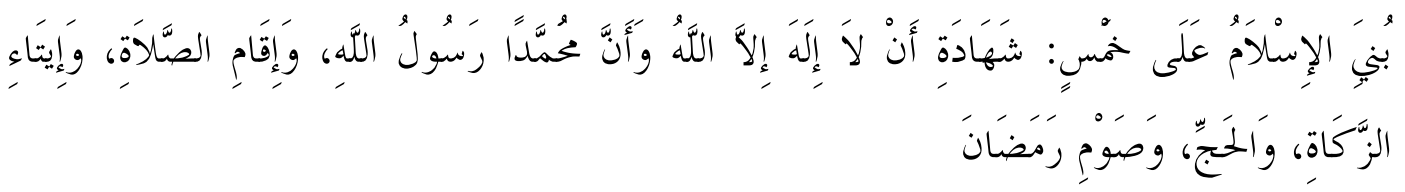

Artinya:

"Islam dibangun di atas lima rukun: syahadat la ilaha illallah muhammadurrasulullah, menegakkan salat, membayar zakat, haji, dan puasa Ramadan."1

Meski ibadah tahunan ini diwajibkan atas setiap individu muslim, akan tetapi Allah Ta'ala tetap saja memberikan keringanan sebagaimana ajaran-ajaran Islam yang lainnya, tegas tetapi ada sisi luwes (keringanan) dan tidak menghendaki kesulitan akan tetapi justru kemudahan untuk setiap pemeluknya. Keringanan seperti ini diberikan bagi orang-orang tertentu karena sebab-sebab tertentu pula. Orang yang sakit adalah salah satunya, ia diberikan keringanan untuk tidak berpuasa, bila dengan sakitnya, ia itu justru saat berpuasa akan memberinya mudarat. Bahkan, bila orang yang sakit tersebut memaksakan dirinya untuk berpuasa maka akan berbahaya bagi keselamatan jiwanya.

Para ulama telah sepakat mengenai hal ini, bolehnya orang sakit untuk tidak berpuasa. Dalil mengenai hal ini adalah firman Allah Ta'ala:

${ }^{1}$ H.R. Bukhari no. 8 dan Muslim no. 16. 


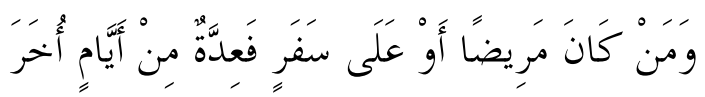

Terjemahnya:

"Dan barang siapa sakit atau dalam perjalanan (lalu ia berbuka), maka (wajiblah baginya berpuasa), sebanyak hari yang ditinggalkannya itu, pada hari-hari yang lain." (Q.S. al-Baqarah/2: 185).

Di dalam kitab Shahih Fiqh Sunnah (2/119) disebutkan bahwa untuk orang sakit ada 3 (tiga) kondisi:

1) Kondisi jika sakitnya ringan dan tidak berpengaruh apa-apa jika tetap berpuasa. Contohnya adalah pilek, pusing atau sakit kepala ringan, dan perut keroncongan. Untuk kondisi pertama ini tetap diwajibkan untuk berpuasa.

2) Kondisi jika sakitnya bisa bertambah parah atau akan menjadi lama sembuhnya dan menjadi berat jika berpuasa, namun hal ini tidak membahayakan. Untuk kondisi ini dianjurkan untuk tidak berpuasa dan dimakruhkan jika tetap ingin berpuasa.

3) Kondisi jika tetap berpuasa akan menyusahkan dirinya bahkan bisa mengantarkan pada kematian. Untuk kondisi ini diharamkan untuk berpuasa.

Hal ini berdasarkan firman Allah Ta'ala:

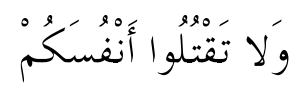

Terjemahnya:

"Dan janganlah kamu membunuh dirimu." (Q.S. al-Nisa'/4: 29).

Berdasarkan ketiga kondisi tersebut maka disimpulkan bahwa penyakit yang memberatkan seseorang dalam melakukan puasa maka bisa menjadi uzur untuk tidak berpuasa menurut syariat, sedangkan jika tidak sampai memberatkan maka bukan merupakan uzur untuk tidak berpuasa.

Masalah yang timbul kemudian adalah bagaimana hukum berpuasa bagi orang-orang yang positif terpapar penyakit virus covid-19? Bagaimana hukum berpuasa bagi mereka yang positif terjangkit covid-19 namun tidak menunjukkan gejala? Bagaimana pula dengan para tenaga kesehatan yang menangani pasien positif terjangkit covid-19?

Penelitian ini dilakukan dengan tujuan untuk menjelaskan hukum puasa dalam masa pandemi covid-19 baik bagi orang-orang yang positif terpapar covid-19, mereka yang positif covid-19 namun tidak menunjukkan gejala, dan para tenaga kesehatan yang menangani pasien covid-19. Penelitian ini menggunakan metode pendekatan kualitatif deskriptif adalah upaya untuk 
memahami berbagai konsep yang ditemukan dalam proses penelitian, dengan menggunakan teknik content analysis (analisis isi) dan riset kepustakaan (library research). Teknik content analysis merupakan metode penelitian yang digunakan untuk mengetahui simpulan dari sebuah teks/naskah. Atau dengan kata lain, analisis isi merupakan metode penelitian yang ingin mengungkap gagasan penulis yang termanifestasi maupun yang laten. Sedangkan riset kepustakaan (library research) pada penelitian ini menggunakan jenis dan sumber data sekunder yang diperoleh dari hasil penelitian, artikel dan buku-buku referensi yang membahas topik yang berkaitan dengan masalah dan fokus penelitian. ${ }^{2}$

\section{PEMBAHASAN}

Orang-orang yang positif terpapar penyakit virus covid-19 adalah mereka yang tergolong sakit yang bisa mendapatkan uzur untuk tidak berpuasa karena dikhawatirkan akan berdampak pada kesehatan dirinya yang akan semakin memburuk.

\section{Hukum Puasa bagi Mereka yang Positif Covid-19 namun Tidak Menunjukkan Gejala}

Mereka dihukumi sebagai orang sakit yang terpapar wabah covid-19 oleh karena adanya virus dalam tubuh yang telah diketahui berdasarkan keterangan medis meskipun belum menunjukkan gejala sehingga boleh untuk tidak berpuasa, yang dikhawatirkan akan menderita sakit jika dia berpuasa, akan bertambah parah atau akan bertambah lama sembuhnya.

Allah Ta'ala berfirman:

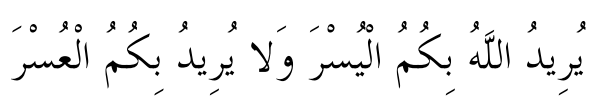

Terjemahnya:

"Allah menghendaki kemudahan bagimu, dan tidak menghendaki kesukaran bagimu." (Q.S. al-Baqarah/2: 185).

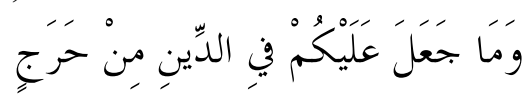

Terjemahnya:

"Dia telah memilih kamu dan Dia sekali-kali tidak menjadikan untuk kamu dalam agama suatu kesempitan.” (Q.S. al-Hajj/22: 78).

${ }^{2}$ Azwar Iskandar dan Khaerul Aqbar, Kedudukan Ilmu Ekonomi Islam di Antara Ilmu Ekonomi dan Fikih Muamalah: Analisis Problematika Epistemologis, Nukhbatul 'Ulum: Jurnal Bidang Kajian Islam, Vol. 5, No. 2 (2019), h. 88-105. 
Nabi Muhammad Shallallahu 'Alaihi Wasallam bersabda:

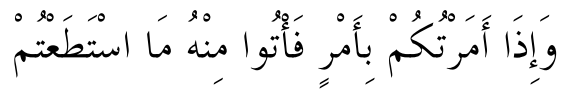

Artinya:

"Jika aku memerintahkan kalian untuk melakukan suatu perkara, maka lakukanlah semampu kalian."3

\section{Hukum Puasa Bagi yang Masih Sehat di Tengah Kondisi Wabah}

Ulama kita memegangi kaidah:

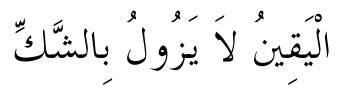

Artinya:

"Keyakinan tidak bisa dihilangkan dengan suatu keraguan."

$$
\text { الحقائق لا تبنى على الأوهام }
$$

Artinya:

"Hakikat sesuatu tidak boleh didasari oleh sangkaan-sangkaan."

Artinya, suatu penyakit akan menjadi uzur untuk tidak berpuasa apabila sakit itu memang terbukti ada dan memberatkan untuk melakukan puasa, bukan sekadar sangkaan yang dibuat-buat, oleh karena sekadar sangkaan tidaklah dianggap. Adapun seorang mukalaf (orang yang terkena beban syariat) sejatinya sedang bermuamalah dengan Allah Ta'ala dan hendaknya ia melakukan yang terbaik.

Darul Ifta Mishriyah (Lembaga Fatwa Mesir) sebagaimana yang dilansir di media Sabq telah mengeluarkan fatwa berkaitan dengan puasa Ramadan saat wabah covid-19, salah satu bunyi dari fatwa tersebut bahwa, "Mereka yang masih sehat dan belum terinfeksi virus covid-19 dan terpenuhi atasnya syaratsyarat puasa dan tidak memiliki uzur yang menghalanginya untuk berpuasa maka wajib baginya untuk berpuasa, bahkan menjadi prioritas, oleh karena puasa bisa meningkatkan imun." Di halaman resmi twitter milik Darul Ifta Mishriyah juga mengeluarkan pernyataan bahwa, "Kekhawatiran akan terinfeksi virus covid-19 bukanlah menjadi alasan untuk tidak berpuasa." ${ }^{6}$

\footnotetext{
${ }^{3}$ H.R. Bukhari no. 7288 dan Muslim no. 1337.

${ }^{4}$ Al-Asybah wa al-Nazhair oleh Ibnu Nujaim, h. 47.

${ }^{5}$ Bada-i' al-Fawaid, 3/62.

${ }^{6} \mathrm{https}: / /$ sabq.org/VH9jCM
} 


\section{Hukum Puasa bagi Tenaga Kesehatan yang Menangani Pasien Covid-19}

Ibadah puasa Ramadan merupakan salah satu dari 5 rukun Islam yang hukumnya wajib dilakukan oleh setiap individu muslim yang mukalaf dan haram bagi seorang muslim untuk meninggalkan puasa Ramadan atau membatalkannya kecuali dengan uzur yang dibenarkan oleh syariat, yaitu:

1) Orang lanjut usia yang tidak lagi mampu untuk berpuasa.

2) Musafir.

3) Orang yang sakit yang jika berpuasa akan menyebabkan kemudaratan bagi kesehatannya.

4) Ibu hamil atau menyusui jika khawatir terhadap kesehatan dirinya atau anaknya.

5) Meninggalkan puasa untuk ketahanan tubuh saat berperang melawan orang kafir. ${ }^{7}$

6) Wanita yang haid atau nifas.

Selain dari golongan di atas maka tidak diperkenankan untuk meninggalkan puasa. Kecuali dalam kondisi darurat, yaitu ketika berpuasa merasa haus atau sangat lapar yang membuatnya yakin bahwa jika tidak minum atau makan akan menimbulkan kemudaratan bagi dirinya, hal ini bisa terjadi jika seseorang melakukan kerja berat. Adapun jika ini terjadi maka dia boleh makan atau minum secukupnya kemudian melanjutkan puasanya sampai terbenam matahari dan mengganti puasanya di hari kemudian. ${ }^{8}$ Hal ini berdasarkan firman Allah Ta'ala:

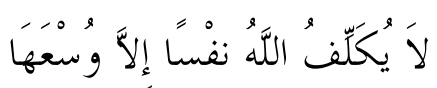

\footnotetext{
${ }^{7}$ Pendapat ini berdasarkan hadis nabi Muhammad saw. yang diriwayatkan oleh sahabat abu sa'̄̄o al-Khudrī ra. yang dalam hadis tersebut disebutkan bahwa nabi bersabda :' Sesungguhnya kalian sudah dekat dengan musuh kalian, sedangkan berbuka akan membuat kalian lebih kuat, maka berbukalah", hadis ini dalam Șahịh Muslim no. 1120, Muslim ibn al-Hajjāj alNaisābūri, al-Musnad al-Saḥ̄ḥ al-Mukhtaṣar, Juz 2 (Beirut: Dār Iḥyā’ al-Turās al-`Arabi, t.th.), h. 789. Al-Munāwi menyebutkan bahwa 'illah di sini ada al-fițr bukan safar, lihat: Zain al-Dīn Muhammad 'Abd al-Raūf al-Munāwi, Faị̣ al-Qadīr Syarh al-Jamī' al-Sagī̄r, Juz 2 (Cet. 1; Mesir: al-Maktabah al-Tijāriyyah al-Kubrā, $1356 \mathrm{H}$ ), h. 555. Dan pendapat inilah yang dipilih oleh Ibn Taimiyyah, lihat: Muhammad ibn Qayyim al-Jawziyyah, Zād al-Ma'ād F̄̄ Hady Khair al-'Ibād, Juz 2 (Cet. 27; al-Kuwait: Maktabah al-Manār al-Islāmiyyah, 1994), h. 50, Ismā'îl ibn 'Umar ibn Kas̀̄ir al-Bașrī al-Dimasyq̄̄, al-Bidāyah wal-Nihāyah, Juz 14 (Cet. 1; Beirut: Dār Ihyā̄' al-Turāì al'Arabi, 1988), h. 30.

${ }^{8}$ Mazhab ini yang pernah difatwakan oleh Komisi Tetap Riset dan Fatwa Saudi Arabia di bawah pimpinan Syekh Abdul Aziz bin Baz, lihat: Al-lajnah al-Dāimah Lil Buhūs̀ al-'Ilmiyyah wal-Iftā', Fatā wā al-lajnah al-Dāimah vol 1, Juz 10 (Riyad: Riāsatu Idāratil Buhūs̀ al-'Ilmiyyah wal-Iftā', t.th), h. 236.
} 
Terjemahnya:

"Allah tidak membebani seseorang melainkan sesuai dengan kemampuannya." (Q.S. al-Baqarah/2: 286).

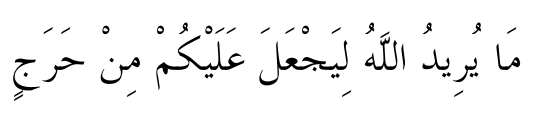

Terjemahnya:

“Allah tidak hendak menyulitkan kamu.” (Q.S. al-Maidah/5: 6)

Syekh Ibn Utsaimin pernah ditanya tentang para pekerja berat, jika pekerjaannya membuat mereka sangat lelah, apakah pada saat itu boleh mereka berbuka? Beliau rahimahullah menjawab:

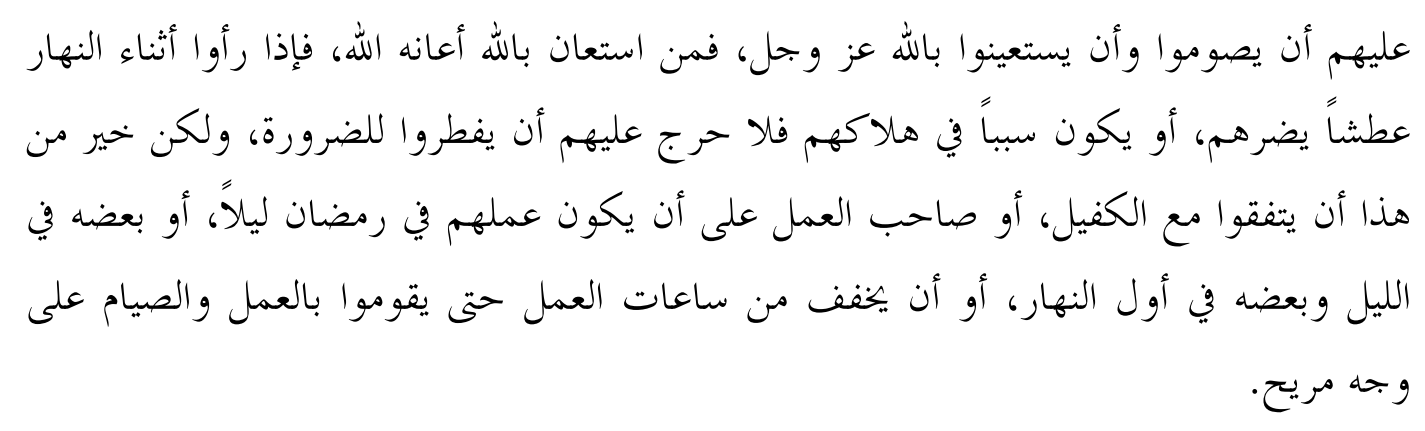

Artinya:

“Mereka harus tetap puasa dan meminta pertolongan kepada Allah Ta'ala, barang siapa yang minta pertolongan kepada Allah, maka niscaya Dia akan berikan pertolongan, dan jika pada siang hari mereka merasa sangat kehausan yang bisa menimbulkan mudarat pada diri mereka, atau bisa membahayakan jiwa mereka, maka boleh bagi mereka untuk berbuka karena darurat, akan tetapi sebaiknya mereka bersepakat dengan pihak yang berwenang atau pemilik proyek supaya pekerjaan mereka selama bulan suci Ramadan hanya di malam hari, atau sebagian malam dan sebagiannya di awal pagi atau minta keringanan jam kerja agar mereka bisa memadukan antara pekerjaan dan tetap berpuasa dalam kondisi yang fit." $"$

${ }^{9}$ Muhammad bin Șālih al-‘Uṡaimīn, Majmū' Fatā wā Wa Rasāil Faḍilah al-Syaikh Muhammad ibn Ṣālih al- 'Usaimīn, Juz 19 (Dār Śurayyā: Dār al-Wațan, 1413 H), h. 89. 
Para ulama besar Saudi yang tergabung dalam Komisi Tetap Riset dan Fatwa di masa kepemimpinan Syekh Abdul Aziz bin Baz rahimahullah pernah ditanya tentang masalah ini secara khusus, lalu mereka menjawab:

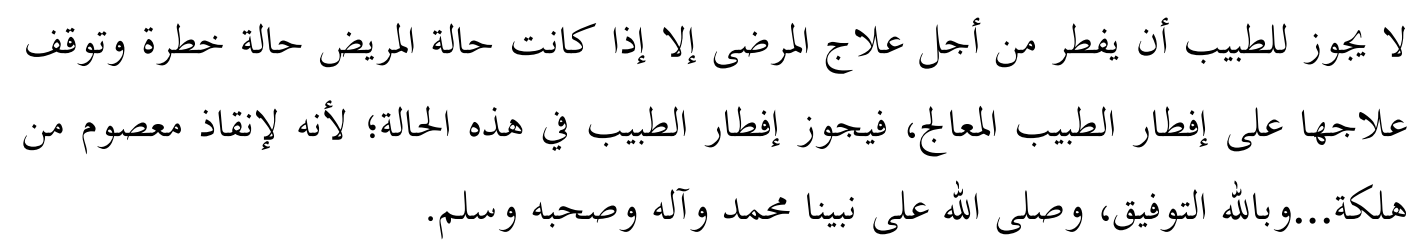

Artinya:

"Seorang dokter tidak diperbolehkan berbuka karena mengobati orang sakit, kecuali kalau kondisi pasien dalam kondisi kritis dimana pengobatannya tergantung dengan berbukanya dokter yang menangani. Maka dokter tersebut diperbolehkan berbuka dalam kondisi seperti ini, karena itu termasuk menyelamatkan jiwa yang dilindungi dari kebinasaan. Wabillahittaufiq, selawat dan salam semoga terlimpahkan kepada Nabi kita Muhammad, keluarga dan para sahabatnya."10

Masalah berikutnya, jika seorang tenaga kesehatan (Nakes) atau pekerja berat terpaksa berbuka dikarenakan sangat lelah dan kelaparan atau kehausan maka apakah setelah berbuka secukupnya dia harus melanjutkan puasanya hingga Magrib lalu nanti mengqada di hari lain? Telah disebutkan bahwa:

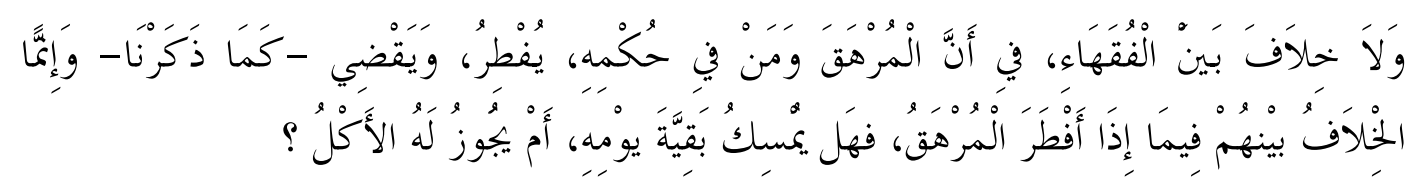

Artinya:

"Tidak ada ikhtilaf di kalangan ulama tentang bolehnya berbuka bagi seseorang yang sangat lelah dan capek (sampai tidak bisa mempertahankan puasanya) dan yang semisalnya, serta wajib baginya menggantinya, sebagaimana yang telah kami sebutkan, adapun ikhtilaf di kalangan mereka tentang seseorang yang terpaksa membatalkan puasa dikarenakan alasan di atas, apakah (setelah dia berbuka secukupnya) dia

${ }^{10}$ Al-lajnah al-Dāimah Lil Buhūs̀ al-'Ilmiyyah wal-Iftā', Fatā wā al-lajnah al-Dāimah vol 2, Juz 9 (Riyad: Riāsatu Idāratil Buhūs̀ al-'Ilmiyyah wal-Iftā', t.th), h. 203-204. 
tetap wajib melanjutkan puasanya di sisa waktu pada hari tersebut hingga Magrib atau boleh baginya melanjutkan makan?"11

Masalah ini diikhtilafkan oleh para ulama sebagaimana disebutkan di atas, di antara mereka ada yang mewajibkan untuk melanjutkan puasanya hingga terbenamnya matahari, seperti Syekh Ibn Baz rahimahullah saat ditanya tentang permasalah yang serupa beliau menjawab:

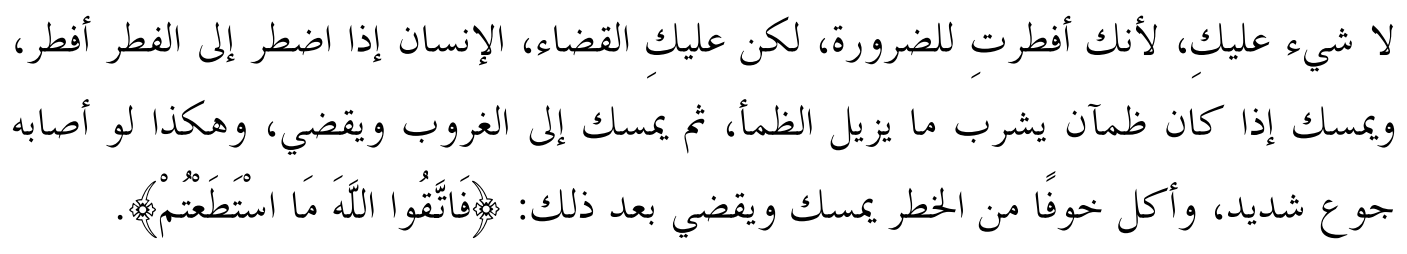

Artinya:

"Anda tidak berdosa karena Anda berbuka dalam keadaan darurat, akan tetapi wajib bagimu mengqadanya di hari lain. Seseorang jika terpaksa berbuka maka boleh baginya berbuka, jika ia sangat kehausan maka dia berbuka sekadar menghilangkan dahaganya lalu menahan diri hingga Magrib dan wajib baginya mengqada. Demikian pula jika sangat kelaparan yang dikhawatirkan jika tetap berpuasa akan membahayakan dirinya maka boleh baginya makan (secukupnya) setealah itu dia menahan diri hingga waktu Magrib lalu mengqada di hari lain. Allah Ta'ala berfirman (artinya): Bertakwalah kepada Allah sekemampuan kalian."12

Berbeda dengan pandangan Syekh Ibn Baz rahimahullah dalam hal ini, Syekh Ibnu Utsaimin ketika ditanya tentang seseorang yang berbuka di bulan Ramadan karena uzur yang dibenarkan syariat, apakah setelah berbuka yang secukupnya wajib baginya menahan diri untuk tidak makan dan minum di waktu yang tersisa pada hari tersebut? Beliau rahimahullah menjawab:

$$
\text { فأجاب فضيلته بقوله: يبوز له أن يأكل ويشرب لأنه أفطر بعذر شرعي، وإذا أفطر بعذر شرعي المسألتين. }
$$

\footnotetext{
${ }^{11}$ Kementrian Wakaf dan Bidang Keislaman Kuwait, al-Mausū'ah al-Fiqhiyyah al-Kuwaitiyyah, Juz 28 (Cet. 2; Kuwait: Wazārah al-Awqāf al-Kuwait, 1427 H), h. 57.

12 'Abdul 'Azīz ibn Bāz, Fatā wā Nūr 'alā al-Darb, Juz 16 (Cet. 1; Riyad: al-Riāsah al-'Āmmah lil Buhuś al-'Ilmiyyah wal-Iftā', 2010), h. 164.
} 
Artinya:

"Boleh baginya makan dan minum karena dia berbuka disebabkan uzur yang dibenarkan syariat. Seseorang yang membatalkan puasanya karena uzur yang dibenarkan syariat maka hilang baginya kehormatan hari tersebut sehingga boleh baginya makan dan minum. Hal ini berbeda dengan seseorang yang membatalkan puasanya di siang hari Ramadan tanpa uzur, maka kita mengharuskan baginya untuk menahan diri di waktu yang tersisa pada hari tersebut di samping itu dia juga wajib mengqada puasanya. Maka wajib memperhatikan perbedaan antara dua masalah yang berbeda ini." 13

\section{KESIMPULAN}

Berdasarkan penjelasan di atas dapat disimpulkan beberapa hal yaitu:

Pertama, orang-orang yang positif terpapar penyakit virus covid-19 adalah mereka yang tergolong sakit yang bisa mendapatkan uzur untuk tidak berpuasa karena dikhawatirkan akan berdampak pada kesehatan dirinya yang akan semakin memburuk.

Kedua, mereka yang positif covid-19 namun tidak menunjukkan gejala, dihukumi sebagai orang sakit yang terpapar wabah covid-19 oleh karena adanya virus dalam tubuh berdasarkan keterangan medis meskipun belum menunjukkan gejala sehingga boleh untuk tidak berpuasa, dalam mana dikhawatirkan akan menderita sakit jika dia berpuasa, akan bertambah parah atau akan bertambah lama sembuhnya.

Ketiga, mereka yang masih sehat dan belum terinfeksi virus covid-19 dan terpenuhi atasnya syarat-syarat puasa dan tidak memiliki uzur yang menghalanginya untuk berpuasa maka wajib baginya untuk berpuasa.

Keempat, tenaga medis yang menangani pasien covid-19 tetap wajib berpuasa. Apabila dalam menjalankan tugas ada di antara mereka yang sangat haus, lapar atau sangat letih yang dikhawatirkan akan rentan jatuh sakit dan terjangkit virus covid-19, maka boleh baginya membatalkan puasanya. Sebagian ulama memandang bahwa dia hanya boleh makan atau minum secukupnya,

${ }^{13}$ Muhammad bin Ṣālih al-'Us̉aimīn, Majmū' Fatāwā Wa Rasāil Faḍ̂lah al-Syaikh Muhammad ibn Șālih al- 'Uśaimīn, Juz 19 (Dār Śurayyā: Dār al-Wațan, 1413 H), h. 100. 
kemudian melanjutkan puasanya sampai terbenamnya matahari, serta mengqadanya di kemudian hari. Akan tetapi, kebanyakan ulama tidak mewajibkan seseorang untuk melanjutkan menahan dirinya dari makan dan minum sampai Magrib jika dia membatalkan puasanya karena uzur yang dibenarkan syariat. Wallahu a'lam.

\section{DAFTAR PUSTAKA}

Al-Qur'an

Al-'Uṡaimīn, Muhammad bin Șālih . (1413 H). Majmū' Fatāwā Wa Rasāil Faḍilah al-Syaikh Muhammad ibn Ṣālih al- 'Usaimīn, Juz 19. Dār Surayyā: Dār al-Wațan. h. 89.

Al-'Uśaimīn, Muhammad bin Șālih . (1413 H). Majmū' Fatāwā Wa Rasāil Faḍ̂lah al-Syaikh Muhammad ibn Șālih al- 'Usiaimīn, Juz 19. Dār Surayyā: Dār al-Wațan. h. 100.

Al-Jawziyyah, Muhammad ibn Qayyim. (1994). Zād al-Ma'ād F̄̄ Hady Khair al'Ibād, Juz 2, Cet. 27. Al-Kuwait: Maktabah al-Manār al-Islāmiyyah. h. 50.

Al-lajnah al-Dāimah Lil Buhūì al-'Ilmiyyah wal-Iftā'. (t.th.). Fatāwā al-lajnah alDāimah vol 2, Juz 9. Riyad: Riāsatu Idāratil Buhūs̀ al-'Ilmiyyah wal-Iftā'. 203-204.

Al-Lajnah al-Dāimah Lil Buhūì al-'Ilmiyyah wal-Iftā'. (t.th.). Fatāwā al-lajnah al-Dāimah vol 1, Juz 10. Riyad: Riāsatu Idāratil Buhūs̀ al-'Ilmiyyah walIftā'.h. 236.

Al-Munāwi, Zain al-Dīn Muhammad 'Abd al-Raūf. (1356 H). Faị al-Qadīr Syarh al-Jamī’ al-Sagīr, Juz 2, Cet. 1. Mesir: al-Maktabah al-Tijāriyyah alKubrā. h. 555.

Al-Naisābūri, Muslim ibn al-Hajjāj. (t.th.). Al-Musnad al-Ṣaḥ̄ḥ al-Mukhtaṣar, Juz 2. Beirut: Dār Iḥyā’ al-Turās al-'Arabi. h. 789.

Ibn Bāz, Abdul 'Azīz . (2010). Fatāwā Nūr 'alā al-Darb, Juz 16, Cet. 1. Riyad: al-Riāsah al-'Āmmah lil Buhusis al-'Ilmiyyah wal-Iftā'. h. 164.

Ibn Kà̀īr, Ismā’̄̄l ibn 'Umar. (1988). Al-Bidāyah wal-Nihāyah, Juz 14, Cet. 1. Beirut: Dār Iḥyā’ al-Turāì al-‘Arabi. h. 30.

Iskandar, A., Aqbar, K. (2019). Kedudukan Ilmu Ekonomi Islam di Antara Ilmu Ekonomi dan Fikih Muamalah: Analisis Problematika Epistemologis. 
BUSTANUL FUQAHA: Jurnal Bidang Hukum Islam

Vol. 1, No. 2 (2020) Special Issue : Islamic Law Perspective on Covid-19: Hal. 197-208

Website: https://journal.stiba.ac.id

Nukhbatul 'Ulum: Jurnal Bidang Kajian Islam, Vol. 5, No. 2 (2019), h. 88105.

Kementrian Wakaf dan Bidang Keislaman Kuwait. (1427 H). Al-Mausū'ah alFiqhiyyah al-Kuwaitiyyah, Juz 28, Cet. 2. Kuwait: Wazārah al-Awqāf alKuwait. h. 57. 